Heavy viscous media are now being abandoned for bronchography because they remain in the lung for a very long period. Not only may they obscure subsequent alterations in a lesion, but they may also provoke an oil fibrosis. Water-soluble media are now available. These are quickly and completely absorbed, but they are temporarily rather irritating and deeper local analgesia is required to inject them successfully.

\section{Death on the Table}

Q.-Who has the legal responsibility when a patient dies under an anaesthetic, the anaesthetist or the surgeon? Is there any difference between Scottish and English law in this connexion?

A.- - If a patient dies under anaesthesia, responsibility for the death does not necessarily rest upon either surgeon or anaesthetist. Legal responsibility, in the sense presumably intended by the question, will exist only if either surgeon or anaesthetist has failed in the proper execution of his functions as a skilled professional person.

An anaesthetist is an independent expert. Although not legally responsible if the death has resulted from a genuine and understandable error of judgment, he is expected to exercise a degree of skill, care, and judgment commensurate with his professional qualifications and experience. It is his responsibility to assess the fitness of the patient to support the strain of anaesthesia, to advise regarding premedication, to select a suitable form of anaesthesia, to ensure that the administration is satisfactory, and to have available and apply when necessary the appropriate measures for resuscitation. The decision to operate, the choice of operation, and the actual operative procedure is the responsibility of the surgeon, and, again, legal responsibility for a death will only exist if he has failed to exercise that degree of skill, care, and judgment which can reasonably be expected from a professional person of his particular qualifications and experience.

There is no difference between Scots and English Law in the matter. In both countries, the circumstances of the particular case would fall to be considered, and the important elements are, not understandable errors of judgment, but failure to exercise the requisite degree of judgment, skill, and care.

There is no case on record where criminal proceedings or a successful civil action has been taken against a medical man in respect of a death under anaesthesia, although there have been unsuccessful actions.

\section{Diagnosis and Treatment of Congenital Syphilis}

Q. - What surveillance and treatment should be given to the baby of a syphilitic mother who (a) had no treatment during pregnancy; (b) was treated thoroughly during pregnancy?

A.- (a) A baby born of a syphilitic mother who has had no treatment may or may not have contracted the disease, and it should be noted that in those that are born infected there may be no demonstrable $T$. pallidum or clinical manifestations. A child can also acquire the disease during parturition from a mother with an active lesion on the genitalia.

On the clinically normal infant serological tests should be carried out soon after birth and repeated one month, three months, six months, and 12 months later. If all these tests are negative it may be assumed that the child has escaped infection.

In the treatment of congenital syphilis the optimum dosage of penicillin has not yet been established. The dosage recommended varies from 100,000 to 300,000 units of procaine penicillin in arachis oil with $2 \%$ aluminium monostearate daily for 10-15 days. In the emaciated infant it is advantageous to give three-hourly injections of aqueous penicillin $\mathrm{G}$ (total dosage 200,000 to 600,000 units per $\mathrm{kg}$. of body weight). It is not necessary to follow this up with arsenic or bismuth. Relapse, clinical or serological, is extremely rare, and in such cases the course of penicillin $s$ repeated.

(b) Thorough treatment of a syphilitic mother during pregnancy will ensure a non-syphilitic baby, but serological tests should, as a precautionary measure, be carried out at the intervals stated above.

\section{Efficiency of Inunction}

Q.- Some therapeutic substances are given by inunction. What is the evidence that they are absorbed through the skin and exert a pharmacological effect on the underlying tissues? I have in mind medicaments such as the creams which contain adrenaline, and the mercury inunction of former days. If it is true that certain drugs can penetrate the skin in this way, on what does this property depend?

A.- The evidence that some therapeutic substances are absorbed through the skin is that they are excreted in the urine. Thus mercury can be detected in the urine within 24 hours of its inunction. Methylsalicylate can be detected in the urine within one hour. Sulphur and atropine are also absorbed through the skin when applied as ointments. Some say that iodine is, but some deny it. There is, however, no evidence that adrenaline is absorbed through the skin from a cream containing adrenaline. Drugs can readily be drawn through the skin into the general circulation by electrolysis, but as soon as they reach the dermis they are picked up by the blood stream and dispersed throughout the body. Absorption depends chiefly on physico-chemical properties rather than on chemical constitution. Substances to be absorbed must be soluble in both oil and water.

\section{Masks for Industrial Dusts}

Q.-What are the best kinds of mask to use against industrial dusts, such as asbestos powder, which are irritating to the nose and throat? The patient in question develops a dermatitis when rubber is in contact with his skin.

A. - The use of a mask for protracted periods to give protection against dust is not satisfactory, and protection against a' dangerous dust such as asbestos should never be left to this means.

When temporary protection is required, however, the use of a dust respirator has value. The standard models are usually fitted with a rubber face-piece, but it is rare for the particular rubber used in these respirators to give rise to skin trouble. There is, however, on the market a much simpler respirator with an aluminium frame and employing cotton-wool as the filter. This is effective in stopping the inhalation of a certain amount of dust, but it has no official approval for use with asbestos. Many of these masks are to be seen at the Home Office Museum, in Horseferry Road, London, S.W.1, where it is also possible to see examples of effective methods of suppressing dust in industrial processes.

Correction.-In Dr. M. E. M. Herford's letter (Journal, August 22 , p. 441) on breast-feeding in Oxford, the sentence, "Skin infections, particularly eczema, were not frequent in bottle-feds in each age group," should have read, "Skin infections ... were more frequent in bottle-feds ...."

All communications with regard tw editorial business should be addressed to THE EDITOR, BRITISH MEDICAL JOURNAL, B.M.A. HOUSE. TAVISTOCK SQUARE, LONDON, W.C.1. TELEPHONE: EUSTON 4499 . TELEGRAMS Aitiology, Westcent, London. ORIGINAL ARTICLES AND LETTERS forwarded for publication are understood to be offered to the British Medical Journal alone unless the contrary be stated. Medical Journal alone unless the contrary be stated.
Authors desiring REPRINTS should communicate with the Publishing Manager, B.M.A. House, Tavistock Square, W.C.1, on receipt of proofs. proofs are not sent abroad. proofs are not sent abroad.

ADVERTISEMENTS should be addressed to the Advertisement Manager B.M.A. Houre, Tavistock Square, London, W.C.1 (hours 9 a.m. to 5 p.m.). TELEPHONE: EUSTON 4499. TELEGRAMS: Britmedads, MEMBERS', LUBSCR

the Association. the Association. TelePhONe: ELSTON 4499. Telegrams: Medisecra, Westcen!. London. 